University of Michigan Law School

University of Michigan Law School Scholarship Repository

Articles

Faculty Scholarship

1910

\title{
What is Interstate Commerce?
}

Horace LaFayette Wilgus

University of Michigan Law School

Available at: https://repository.law.umich.edu/articles/1328

Follow this and additional works at: https://repository.law.umich.edu/articles

Part of the Business Organizations Law Commons, Commercial Law Commons, and the Supreme Court of the United States Commons

\section{Recommended Citation}

Wilgus, Horace LaFayette. "What is Interstate Commerce?" Mich. L. Rev. 8 (1910): 662-4.

This Response or Comment is brought to you for free and open access by the Faculty Scholarship at University of Michigan Law School Scholarship Repository. It has been accepted for inclusion in Articles by an authorized administrator of University of Michigan Law School Scholarship Repository. For more information, please contact mlaw.repository@umich.edu. 
What is INTERSTATE, CoMmerce?-In the case of International Text-book Company v. Pigg, Advance Sheets May I, I9ro (30 Sup. Ct. 48I) the Supreme Court of the United States, decided April 4, 1910, that a "corporation engaged in imparting instruction by correspondence, whose business involves the solicitation of students in other states by local agents, who are to collect and forward to the home office the tuition fees, and the systematic intercourse between the corporation and its scholars and agents, wherever situated, and the transportation of the needful books, apparatus, and papers," is engaged in interstate commerce, and a state statute which makes the filing of a statement of the financial condition of such a corporation a prerequisite to the right to do such business in such way in the state and to maintain a suit in the state court upon a contract connected therewith, is an unconstitutional interference with interstate commerce.

Mr. Justice Harlan delivered the opinion, and Chief Justice Fuller, and Mr. Justice McKenNa dissented. "The executive offices of the company, as well as the teachers and instructors employed $b y$ it, reside and exercise their respective functions at Scranton [Pa.]. Its business is conducted by preparing and publishing instruction papers, text-books, and illustrative apparatus for courses of study to be pursued by correspondence, and the forwarding. from time to time, of such publications and apparatus to students. In the 
conduct of its business the company employs local or traveling agents, called solicitor-collectors whose duties are to procure and forward to the company at Scranton, from persons in a specified territory, on blanks furnished by it, applications for scholarships in its correspondence schools, and also to collect and forward to the company deferred payments on scholarships. *** The scholarship and instruction papers, text-books and illustrative apparatus called for under each accepted application are sent directly to the applicant, and instruction is imparted by means of correspondence through "the mails, between the company at its office in that city, and the applieant, at his residence in another state." In this case the company had no office in Kansas; the solicitor-collector was employed by the company upon a salary and commission, and he kept and maintained at his own expense an office in Topeka. The contract for a scholarship was sigried by the defend- ant in Kansas, and was accepted by the company at Seranton.

Mr. Justice HarLAN held, as did the state supreme court, that this was "doing business" in the state of Kansas, within the meaning of the statute forbidding doing business unless conforming to the statute. "Its transactions in Kansas, by means of which it secured applications from numerous persons for scholarships, were not single transactions, such as might be deemed incidental to its general business as a foreign corporation, but were parts of its regular business continuously conducted in many states for the benefit of its correspondence schools,"-following Cooper Manufacturing Company v. Ferguson, II3 U. S, 727. Justice Harian quotes Chief Justice Marshail, Gibbons v. Ogden, 9 Wheat 1 ,- "Commerce, undoubtedly, is traffic; but it is something more; it is intercourse," and relies largely on the telegraph cases, Pensacola Tel. Co. v. Western U. Tel. Co..96 U. S. I, and Western U. Tel. Co. v. Pendelton, 122 U. S. 347, holding that "the transmission of intelligence," carrying "only ideas, wishes, orders, and intelligence" across state lines is interstate commerce, and says "If intercourse between persons in different states by means of telegraph messages conveying intelligence or information is commerce among the states, which no state may directly burden or unnecessarily encumber, we cannot doubt that intercourse or communication between persons in different states, by means af correspondence through the mails, is commerce among the states, $* * *$ especially where such intercourse and communication really relate to matters of regular, continuous business, and to the making of contracts and the transportation of books, papers, etc., appertaining to such business."

Commerce includes the subject matter of traffic and intercourse, the fact of traffic and intercourse, and the instrumentalities by which it is carried on. The subject matter may be "things, goods, chattels, merchandise, persons," telegraph or telephone messages, (McCall v. Califormia, I36 U. S. I04; Lottery Cases I88 U. S. 321), and now apparently instruction or knowledge by mail, as above stated.

The fact of intercourse includes the negotiation of the sale of goods, wares and merchandise, which are in other states whether by solicitor or sample (Stockard v. Morgan, 185 U. S. 27; Caldzuell v. North Carolina, 187 U. S. 622); the purchase of goods between citizens of different states, made 
in, either state (McNaughton v. McGirl, 20 Mont. 124, 63 Am. St. Rep. 610; Buttfield v. Stranahan, I92 U. S. 470); communication by telegraph or telephone (cases supra, and Muskogee Tel. Co. v. Hall, -I18 Fed. 382); the transit of persons (Crandall v. Nevada, 6 Wall. 35; Covington Bridge Co. v. Kentucky, 154 U. S. 204, 218); the transportation of persons or property by boat, rail, or express (The Passenger Cases, 7 How. 283; The Daniel Ball, 1o Wall. 557; Crutcher v. Kentucky, I4I U. S. 47); the piping of oil or gas (State v. Indiana \&c. Co., I20 Ind. 575); driving of cattle (Kelly v. Rhoads, I 88 U. S. I), in completion of a commercial transaction across state lines, and the written documents whereby such transactions are effected (Interstate Commerce Commission v. Baird, I94 U. S. 25, 24 Sup. Ct. 563).

As to the instrumentalities, the commerce powers extend to interstate b. 'dges (Luxton v. North River Bridge, I53 U. S. 525), and "from the horse with its rider to the stage coach, from the sailing vessel to the steamboat, from the coach and steamboat to the railroad, and from the railroad to the telegraph, as these new agencies come into use. They were intended for all times and all circumstances,"-(Chief Justice WAITE in Pcnsacola Tel. Co. v. Wcstern U. Tel. Co. supra). In due time the flying machines will undoubtedly be included.

Insurance (Hooper v. California, I55 U. S. 648; NewU York Insurance Co. v. Cravens, 178 U. S. 389), loaning money, (Nelms v. Mortgage Co., 92 Ala. 157), dealing in lands in other states (Honduras \&c. Co. v. Statc Board, 54 N. J. L. 278), or in foreign bills of exchange (Bamberger v. Schoolfield, Ióo U. S. 149), or in futures, Ware and Lcland v. Mobile County, 209 U. S. 405, I21 Am. St. Rep. 21, 24, 28 Sup. Ct. 526), or carrying on a building and loan association business. (Southern Building \& L. Ass'n v. Norman, $98 \mathrm{Ky} .294$ ), or a brokerage or commission business (United States v. Hopkins, I7I U. S. 578 ), or the transfers of corporate shares, (Nezu York v. Reardon, 204 U. S. 152, 27 Sup. Ct. 188), or -the sale or transportation of the waters of one state into another state, (Hudson County Watcr Co. v. McCarter, 209 U. S. 349 , 28 Sup. Ct. 529) is not interstate commerce, in such a sense as to prevent state regulation. Neither is mining (Utley v. Mining Co., 4 Colo. 359), nor the production or manufacture of things intended for interstate commerce, (United States v. E. C. Knight Co., I56 U. S. I; Kidd v. Pearson, I28 U. S. I, 9 Sup. Ct. 6 ), nor gathering them together for the purpose of sending them to other states (Dianond Match Co. v. Ontonagon, I88 U. S. 82), or after sending them there keeping them there for the purpose of use or sale (Brown v. Houston, II4 U. S. 622; Pittsburg Coal Co. v. Bates, 156 U. S. 577) if not in the original package (May v. New Orleans, 178 U. S. 496).

H. L. W. 